Canadian University Music Review

Revue de musique des universités canadiennes

\title{
Hans Rosbaud and the Music of Arnold Schoenberg
}

\section{Joan Evans}

Volume 21, numéro 2, 2001

URI : https://id.erudit.org/iderudit/1014484ar

DOI : https://doi.org/10.7202/1014484ar

Aller au sommaire du numéro

\section{Éditeur(s)}

Canadian University Music Society / Société de musique des universités canadiennes

\section{ISSN}

0710-0353 (imprimé)

2291-2436 (numérique)

Découvrir la revue

\section{Citer cet article}

Evans, J. (2001). Hans Rosbaud and the Music of Arnold Schoenberg. Canadian University Music Review / Revue de musique des universités canadiennes, 21(2), 41-59. https://doi.org/10.7202/1014484ar
Résumé de l'article

Cette étude documente les efforts de Hans Rosbaud (1895-1962) pour promouvoir la musique d'Arnold Schoenberg. L'essai est en grande partie basé sur vingt années de correspondance entre le chef d'orchestre et le compositeur, échange demeuré inédit. Les tentatives de Rosbaud portaient déjà fruit pendant qu'il était en fonction à la radio de Francfort au début des années 1930. À la suite de l'interruption forcée due aux années nazies (au cours desquelles il a travaillé en Allemagne et dans la France occupée), Rosbaud a acquis une réputation internationale en tant que chef d'orchestre par excellence dédié aux œuvres de Schoenberg. Ses activités en faveur de Schoenberg dissimulaient le projet, que la littérature sur celui-ci n'avait pas encore relevé, de ramener le compositeur vieillissant en Allemagne.
All Rights Reserved (C Canadian University Music Society / Société de musique des universités canadiennes, 2002
Ce document est protégé par la loi sur le droit d'auteur. L'utilisation des services d'Érudit (y compris la reproduction) est assujettie à sa politique d'utilisation que vous pouvez consulter en ligne.

https://apropos.erudit.org/fr/usagers/politique-dutilisation/ 


\title{
HANS ROSBAUD AND THE MUSIC OF ARNOLD SCHOENBERG
}

\author{
Joan Evans
}

"There is nothing I long for more intensely (if for anything) than to be taken for a better sort of Tchaikovsky - for heaven's sake: a bit better, but really that's all." This oft-quoted comment of Arnold Schoenberg's was made in a letter to Hans Rosbaud, a conductor who did more than anyone of his generation to fulfil Schoenberg's longing to be considered not as a wild-eyed twelvetone "experimenter," but as a "normal" composer. ${ }^{1}$

Hans Rosbaud was born in Graz, Austria in 1895. He obtained his advanced musical training at Frankfurt's Hoch'sche Conservatorium (where his exact contemporary Paul Hindemith was a fellow student) and remained in Germany throughout his career. Before 1945 this included positions in Mainz, Frankfurt, Münster and (from 1941) German-occupied Strasbourg; after 1945 he accepted positions in Munich and Baden-Baden, combining the latter with the conductorship of Zurich's Tonhalle Orchestra. ${ }^{2}$

From the late 1920s until his death in 1962, Rosbaud was one of Europe's leading exponents of modern music. His carefully prepared and sympathetically executed performances earned him the gratitude of composers and the admiration of critics and audiences alike. Since much of Rosbaud's career was spent in the service of German Radio, a large number of these performances (including many first performances) were recorded-a valuable legacy that spans more than thirty years. Also a vital part of Rosbaud's legacy is his voluminous correspondence, a significant part of which involves the leading composers of the twentieth century.

The music of Rosbaud's compatriot Schoenberg, along with that of Alban Berg and Anton Webern, held a special place of honour in the conductor's affections, while the warm personal relationship between Rosbaud and Schoenberg is documented in their twenty-year-long correspondence, most of which remains unpublished. ${ }^{3}$ The aim of this study, based in large part on this

1 Arnold Schoenberg, Letters, ed. Erwin Stein, trans. Eithne Wilkins and Ernst Kaiser (London: Faber and Faber, 1974), 243 (letter of 12 May 1947).

2Further on Rosbaud's career, see Joan Evans, Hans Rosbaud: A Bio-Bibliography (New York and London: Greenwood Press, 1992).

3 The Schoenberg/Rosbaud correspondence of approximately forty items is preserved in the Schoenberg Collection, Library of Congress (hereafter LC) and in the Hans Rosbaud Papers, Moldenhauer Archives at Washington State University (Pullman, Washington) (hereafter WSU). Six of Schoenberg's letters are published (albeit with omissions) in Letters. Excerpts from three additional letters can be found in Arnold Schönberg, 1874-1951. Lebensgeschichte in Begegnungen, ed. Nuria Nono-Schoenberg (Vienna: Ritter Klagenfurt, 1992). 
correspondence, is to document fully Rosbaud's efforts on behalf of Schoenberg and his music. These efforts already bore fruit during the late Weimar period, while in the postwar years, after the forced hiatus of the Nazi era, Rosbaud became known as the Schoenberg conductor par excellence. His efforts on Schoenberg's behalf included a plan that until now has gone unnoticed in the Schoenberg literature, namely, to bring the aging composer back to Europe. Schoenberg was keenly interested in Rosbaud's plan, which because of administrative difficulties, however, was eventually (if reluctantly) abandoned.

In the autumn of 1929 Rosbaud was engaged as conductor of the newly established Frankfurt Radio Symphony Orchestra. Shortly thereafter he was also appointed musikalischer Leiter, with control over the station's music programming. Thanks to Rosbaud's outstanding musical gifts-and his prodigious energy-Frankfurt Radio assumed a position of importance not only in the city's musical life, but throughout Germany and beyond. Until the Nazi takeover of January 1933, prominent soloists from all over Europe visited the radio station to perform under Rosbaud's baton, and composers were invited to conduct, perform, lecture, assist at rehearsals, and attend performances of their works.

On 16 December 1929, during his very first season at Frankfurt Radio, Rosbaud presented the local premiere of Schoenberg's Five Pieces for Orchestra, op. 16. The demanding conductor devoted ten full rehearsals to the preparation of the work. In a concert aired the following April, Rosbaud conducted the first performance of Begleitmusik zu einer Lichtspielszene, op. 34 , an event predating by more than six months the acknowledged world premiere, Otto Klemperer's performance at the Kroll Opera on 6 November of that year. ${ }^{4}$

The highlight of the 1930/31 season was Rosbaud's performance of Schoenberg's Variations for Orchestra, op. 31, a work that had not been played since Wilhelm Furtwängler's world premiere of December 1928. ${ }^{5}$ Prior to the performance, Rosbaud visited Schoenberg in Berlin. The composer accepted an invitation to assist at the final rehearsals and to deliver an introductory radio lecture-the first of three essays to be written at Rosbaud's instigation.

The performance of the Variations, op. 31 took place on 23 March 1931; on the previous day Schoenberg delivered his illustrated lecture. ${ }^{6}$ The composer

4See Joan Evans, "New Light on the First Performances of Arnold Schoenberg's Opera 34 and 35," Journal of the Arnold Schoenberg Institute 11 (1988): 163-73. The Frankfurt performance took place on 28 April 1930. See also note 30 below.

5 In a letter to Furtwängler written on 4 June 1929, Schoenberg expressed his disappointment that the conductor had not performed the work again. Referring to the hissing that had greeted the premiere, he wrote, "Frankly, I expected that you would repeat the piece at the next concert, showing the rabble that you only do what you consider right!" (Letters, 134).

6Published in Arnold Schönberg. Gesammelte Schriften I, ed. I. Vojtech (Nördlingen and Reutlingen: S. Fischer, 1976), 255-71. Musical examples were provided by the pianist and composer Erich Itor Kahn (Rosbaud's assistant until 1933) and by the Frankfurt Radio orchestra. Recordings were 
had never heard the work played. That he was pleased by the performance is evident from the fulsome praise he bestowed on Rosbaud in a letter written after his return to Berlin. Declaring himself to be "most unusually pleased" by Rosbaud's performance, Schoenberg singled out those very qualities that were to distinguish the conductor's performances throughout his career: clarity, love, and a sense of the overall shape of the work. ${ }^{7}$

The following winter, on 22 February 1932, Rosbaud presented the world premiere of Schoenberg's Four Orchestral Songs, op. 22, works that had been completed in 1916 but never performed. The soloist, Hertha Reinecke, had been engaged at Schoenberg's suggestion. ${ }^{8}$ Concern for his health forced the composer to cancel his plans to travel to Frankfurt from Spain, where because of his asthma he was spending the winter. On the day prior to the concert Schoenberg's introductory lecture, written for the occasion, was read by Rosbaud. ${ }^{9}$

One year later Schoenberg made his second, and final, visit to Frankfurt Radio, where on 12 February 1933-less than two weeks after the Nazi takeover-he delivered a lecture on Brahms as part of the activities celebrating the centenary of that composer's birth. ${ }^{10}$ The lecture, the last of the three essays we owe to Rosbaud's instigation, is well known in Schoenberg's 1947 revision, published in Style and Idea as "Brahms the Progressive." 11 This occasion marked Schoenberg's last public appearance in Germany. On 17 May the composer, his wife Gertrud and their infant daughter Nuria left Hitler's Germany; Rosbaud and Schoenberg never met again. ${ }^{12}$

made of parts of Schoenberg's lecture, as well as a short excerpt from the performance the following day. Copies of these were presented to the composer by Rosbaud (see his letter of 31 August 1931 to Schoenberg) and are preserved at the Arnold Schönberg Center, Vienna (hereafter ASC). Two pages from Schoenberg's typescript are reproduced in Nono-Schoenberg, Arnold Schönberg, 282, which also includes excerpts from Schoenberg's letter of 14 March 1931 to Rosbaud (pages 282-83). This is the second of two letters from Schoenberg dealing with preparations for his Frankfurt visit. The first, written on 1 March and concerning financial arrangements, marks the beginning of the Schoenberg/Rosbaud correspondence.

7 The passage in question, "Ich habe also mehr als die Genugtuung des Komponisten gehabt, der sein Werk mit Klarheit, mit Liebe, mit Gestaltung vorgetragen hört ...," was inadvertently omitted in both the German and English-language editions of the composer's correspondence (letter of 15 April 1931). The letter is reproduced in Nono-Schoenberg, Arnold Schönberg, 282.

8 Letter of 12 June 1931 to Rosbaud. An incomplete recording of the premiere survives at ASC.

9The essay is published in Arnold Schönberg, Gesammelte Schriften I, 286-300. Three of Schoenberg's letters to Rosbaud concerning preparations for his proposed trip to Frankfurt are published in Letters (pp. 156-57, 159-60, 161-62).

10Rosbaud had left the choice of topic to Schoenberg. After several months of deliberation (and in reply to Rosbaud's urgent request of 3 January), the composer wrote on 7 January, "Would you be interested in a lecture on Brahms?" (Letters, 170).

11 Style and Idea: Selected Writings of Arnold Schoenberg, ed. Leonard Stein (London: Faber and Faber, 1975), 398-441. The 1933 version has been published in recent years, both the German original (Ludwig Finscher, “Arnold Schönbergs Brahms-Vortrag," in Neue Musik und Tradition, ed. J. Kuckertz et al. [Laaber: Laaber Verlag, 1990], 485-500) and a vis-à-vis English translation (Thomas McGeary, "Schoenberg's Brahms Lecture," Journal of the Arnold Schoenberg Institute 15 [1992]: 5-99).

12Between 1929 and 1933 Rosbaud also programmed at Frankfurt Radio Schoenberg's Six Pieces for Men's Chorus, op. 35 (29 November 1931; see Evans, "New Light on the First Performances of Arnold Schoenberg's Opera 34 and 35," 170), and the Serenade, op. 24 (30 June 1932). An incomplete recording of the latter performance survives at ASC. 
In early May 1933 Rosbaud attended the first Maggio Musicale in Florence. As part of a lecture on music programming for German Radio that he delivered on 2 May, Rosbaud stressed the duty of radio towards modern music. As representative German composers he named Pfitzner, Hindemith-and Schoenberg, whose music, however, could now no longer be performed in that country. Rosbaud had intended to illustrate his lecture with Frankfurt Radio's Schoenberg recordings, but unfortunately, as Alban Berg reported home to his wife, "the gramophone didn't work."13

Contact between Rosbaud and Schoenberg was sporadic during the Nazi period. Significantly, Rosbaud's letters to Schoenberg were written while he was out of the country; he requested that the composer reply to his private address. On 1 October 1936 Rosbaud wrote from Amsterdam "just to assure you of my steadfast convictions concerning you and your work." ${ }^{1+} \mathrm{He}$ recalled Schoenberg's memorable 1931 visit to Frankfurt Radio, and added in closing, "Keep your good memories of me, dear Herr Professor. That is the wish that lies closest to my heart."15 The following summer, on 25 August 1937, he wrote more fully from Salzburg, informing Schoenberg of his departure from Frankfurt Radio in favour of a position as Generalmusikdirektor of Münster, where he hoped to find greater "artistic freedom." 16 He thanked Schoenberg for sending the birth announcement of his son Ronald, an act that reassured him "that you have not forgotten me." Noting that his temporary absence from Germany made it possible for him to write openly, Rosbaud added, "I would like to write to you more often, but it is not always very easy; you do understand." ${ }^{17} \mathrm{He}$ also shared with Schoenberg his plan (ultimately unsuccessful) to secure a position in the United States. The Münster position was to be but an interim step. What Rosbaud did not mention was that his decision to escape the politically charged atmosphere of Frankfurt Radio for provincial Münster had been hastened by the unpleasant publicity surrounding the dismissal of the radio station's second Kapellmeister, Josef Felix Hess. In a court case brought against Frankfurt Radio, Hess, a fervent Nazi, accused his superior of behaving in a "Jewish manner," citing as proof Rosbaud's continuing support of modernist composers, especially Hindemith and Stravinsky. ${ }^{18}$

13 Alban Berg, Letters to his Wife, trans. Bernard Grun (New York: St. Martin's Press, 1971), 408-9. A photograph of Berg and Rosbaud taken during the festival is reproduced in Willi Reich, Alban Berg, trans. Cornelius Cardew (New York: Harcourt, Brace and World, 1965), facing page 113. Also attending the Maggio Musicale was the Kolisch Quartet, who performed Schoenberg's String Quartet No. 1.

14"Der Zweck meines heutigen Briefes ist nur die Versicherung meiner unwandelbaren Gesinnung Ihnen und Ihrem Werk gegenüber."

15"Behalten Sie mich, lieber Herr Professor, in gutem Angedenken, das ist die mir am meisten am Herz liegende Bitte."

16 "Ich habe dort einen großen und nicht unwichtigen Wirkungskreis und auch eine gewisse optimale künstlerische Freiheit."

17 "Nochmals möchte ich Ihnen, lieber Herr Professor, von Herzen danken, daß Sie mir die Geburtsanzeige geschickt haben und daß ich daraus ersehen habe, daß Sie mich nicht vergessen haben. Ich bin auch froh, daß ich Ihnen hier aus Salzburg diesen ausführlichen Brief schreiben konnte. Ich würde Ihnen gern öfters schreiben, aber es ist nicht immer ganz leicht, Sie verstehen schon."

18Further, see Evans, Hans Rosbaud, 29-34. See also Evans, "Die Rezeption der Musik Igor Strawinskys in Hitlerdeutschland," Archiv für Musikwissenschaft 55 (1998): 91-109. Rumours that 
Rosbaud stayed in Münster until 1941, at which time he accepted the position of Generalmusikdirektor in occupied Strasbourg, where he remained until 1944. (After Joseph Goebbels shut down the theatres in August of that year, Rosbaud returned to Germany, spending the final months of the war directing an orchestra at Munich Radio's Bayreuth studio.) Having traded the politically charged atmosphere of German Radio for the relative isolation of Münster, it is difficult to understand why Rosbaud waded into even more politically sensitive waters as Generalmusikdirektor of an occupied French city (albeit one whose culture also contained strongly Germanic roots). Surely he was aware that the Nazis after 1940, like Kaiser Wilhelm II at the end of the Franco-Prussian war, were determined to make Strasbourg a showcase of German culture, and that as the city's Generalmusikdirektor he would be on the front line of those developments. It is possible that after four years in relative seclusion in Münster, the intensely energetic conductor was tempted by the challenge - and prestige - that the Strasbourg position offered, while his life-long attraction to all things French assuredly played a part in his decision. It is true that Rosbaud was not appointed by the regime, as one might expect, given the strategic importance of the post. Rather, his contract was a private one with the Strasbourg theatre. It is also true that his honourable behaviour in this difficult position won him the respect of Alsatians of both French and German background, a fact attested to by the overwhelming reception he received when he returned as guest conductor shortly after the war. ${ }^{19}$ But it cannot be denied that however good his intentions, as Generalmusikdirektor of occupied Strasbourg, Rosbaud's prodigious musical talents were employed in the service of the Reich's Germanization policy.

After a nine-year hiatus, contact between Rosbaud and Schoenberg was resumed in the summer of 1946. In November of the previous year Rosbaud had been appointed by OMGUS (the American Military Government in Germany) as Generalmusikdirektor of Munich and conductor of the Munich Philharmonic Orchestra. In the midst of the war-torn country, without adequate food, clothing or heat, Rosbaud and his colleagues began the daunting task of rebuilding the city's musical life. The conductor was deeply anxious to re-establish contact with the international musical world. One of his chief concerns was to resurrect from their twelve-year slumber the works of Arnold Schoenberg.

Rosbaud lost little time in resuming his efforts on Schoenberg's behalf. In the spring of 1947 he founded the Philharmonic Studio, a series of concerts modelled, as he informed the composer on 6 April, on the Verein für musikalische Privataufführungen that Schoenberg had established in Vienna in

Rosbaud was Jewish had been circulating since 1933.

19The eminent French critic Claude Rostand, for example, wrote in his obituary of the conductor: "Since it is a Frenchman who writes these lines, he may say that Hans Rosbaud, despite the delicate situation in which he found himself during the war, understood how to gain the artistic sympathy of the Alsatians. When the dark years were finally over and Rosbaud . . came again to Strasbourg, I was able to see for myself how heartily he was welcomed." Claude Rostand, "Adieu, Hans Rosbaud," German trans. H. Strobel, Melos 30 (1963): 50. 
1918. Rosbaud had chosen to inaugurate the series on 31 March with a concert devoted entirely to the Chamber Symphony, op. 9, the work that forty years earlier had "introduced a new era in the history of music." German music "stands today just about where it did in 1906," Rosbaud commented. With the performance of the Chamber Symphony he was attempting to begin again from where the thread had been "violently broken." 20 The work was performed twice. The evening began with a lecture on Schoenberg by Hans Mersmann, followed by Rosbaud's own illustrated analysis of the Chamber Symphony, modelled on the memorable lecture with which Schoenberg had introduced his Variations, op. 31 at Frankfurt Radio in 1931.21

Rosbaud's analysis, Schoenberg replied on 12 May, "strikes me as an even more important contribution" than his own 1931 essay,

for understanding of my music still goes on suffering from the fact that the musicians do not regard me as a normal, common-or-garden composer who expresses his more or less good and new themes and melodies in a not entirely inadequate musical language. ${ }^{22}$

"I think if your experiment were repeated often enough my music's success would be considerably more "satisfactory'! . . " he added. "Perhaps this conveys to you how and why I esteem your achievement so highly."

The joy afforded the aging composer by the efforts of his European supporters is amply-and touchingly-evident in his postwar correspondence. Equally evident is the sense of isolation that he felt in his California exile, and his bitter disappointment that his adopted homeland displayed so little interest in his music. Ever quick to take offense, especially where his art was concerned, and with a well-developed battle mentality fed by half a century of misunderstanding and neglect, Schoenberg did not hesitate to attribute this lack of recognition to the machinations of the country's prominent musical figures. "Just like the racket of the concert agents, there is now a racket in the making which intends to suppress gradually all European composers," he wrote to a supporter in 1947. ". . . I have been elected to be the first victim of the nationalistic movement." 23 Schoenberg had alluded to this, though less pessimistically, in his first postwar letter to Rosbaud on 22 November 1946. "Perhaps evidence of my activities will be seen in ten or twenty years, when my best students are teaching, and when the nationalistic trend of American 'composers' will have ebbed," he wrote. "Their chance of suppressing us

20"Dieses Werk hat vor nunmehr 40 Jahren einen neuen Abschnitt in der Geschichte der Musik eingeleitet und heute stehen wir in Deutschland beinahe an dem Punkt, an dem die Musik 1906 gestanden hat. So habe ich also versucht, die Brücke zu schlagen und mit Threm Werk dort anzuknüpfen, wo der Faden gewaltsam abgerissen wurde."

21 Schoenberg wrote to Rosbaud on 2 September 1947 that he was happy to hear of Mersmann's participation, "especially since earlier he was not really a supporter of my music." "IIch habe mich auch gefreut zu hören, daß Prof. Mersmann die Analysen vorgetragen hat, besonders da er ja früher nicht eigentlich ein Anhänger meiner Musik war.") A live recording of the performance made for later broadcast has apparently not survived.

22 Letters, 243.

23 Ibid., 250. 
Europeans is only temporary." 24 Schoenberg even suspected "nationalistic" American composers of sabotaging the efforts of his supporters in Europe. "These people regard musical life as a market they mean to conquer," he wrote to Rudolf Kolisch in 1949, "and they are sure they will do it with ease in the colony that Europe amounts to for them." 25

Thus it is hardly surprising that when Rosbaud found it difficult to obtain Schoenberg's recent scores in early postwar Munich, the composer immediately laid the blame on a prominent American composer. William Schuman was a convenient target, for prior to being appointed president of the Juilliard School of Music in 1945, he had been director of publications at Schirmer's, Schoenberg's American publisher. In his letter of 12 May 1947 Schoenberg at first simply referred to Schuman as a young "racketeer." He promised to reveal his name later, "though," he added, with an ironic glance to posterity, "I don't know whether I should do him the favour of figuring in my correspondence (ha, ha!)." 26 Schoenberg need not have worried on this score, for the relevant section is omitted in the published version of the letter. ${ }^{27}$

In the autumn of 1948 Rosbaud left Munich to take over the newly established orchestra of the Südwestfunk in Baden-Baden, then part of the zone occupied by French military forces. Through the efforts of Heinrich Strobel, its musikalischer Leiter, the radio station was fast developing a reputation as a leading centre of new music in Germany. With his long-standing reputation as both an orchestra builder and a staunch advocate of modern music, Rosbaud was the obvious choice for the position.

One of Rosbaud's earliest efforts in Baden-Baden involved an attempt to repatriate not only Schoenberg's music, but the aging composer himself. On 26 August 1948, even before his duties at the Südwestfunk had officially begun, Rosbaud wrote to Schoenberg, tentatively broaching the subject of the composer's return to Germany. ${ }^{28}$ Schoenberg's support is steadily growing in Europe, Rosbaud points out, and his presence in Europe would be of great significance in this regard, especially to the youth. Rosbaud reveals that he had already discussed his plan with Josef Rufer, as well as with a high-ranking

24"Man wird vielleicht die Spuren meiner Tätigkeit in 10-20 Jahren sehen, wenn meine besten Schüler unterrichten und der nationalistische Auftrieb amerikanischer 'Komponisten' abgeebbt haben wird. Ihre Chance uns Europäer zu verdrängen ist nur vorübergehend."

25 Letters, 270.

26 "Es gibt hier einen Raketier (ich werde demnächst, wenn ich Zeit habe, seinen Namen nennenobwohl ich nicht weiß, ob ich ihm ein Gefallen tun soll, in meinem 'Briefwechsel' (ha! ha!) zu figurieren)."

27 Letters, 243-44. In his reply of 26 July, Rosbaud asked Schoenberg to name the "racketeer"; the composer complied in his letter of 2 September. It should be noted, however, that two years earlier, in a letter of May 1945, Schoenberg had included Schuman in a list of American composers in whose works he had found "talent and originality" (ibid., 234).

28Rosbaud may have been emboldened to do so by Schoenberg's positive response to an invitation from Vienna's Bürgermeister, who early in 1946 had called upon Schoenberg to return from exile in order to contribute to the work of reconstruction. In his reply of 6 May, Schoenberg expressed the hope "that circumstances may make my return possible" (ibid., 239). That Rosbaud was aware of this exchange can be deduced from Josef Rufer's unpublished letter of 17 October 1948 to the composer (LC; photocopies of the Schoenberg/Rufer correspondence are held at ASC). 
French military officer. Before discussing the details, however, he would like to know whether Schoenberg would consider such a move. Baden-Baden came through the war unscathed, he writes, and is well situated near the French and Swiss borders. Moreover, as a renowned spa town, it is equipped to deal with many illnesses, including asthma.

Schoenberg's reply of 22 September was enthusiastic. "The idea of taking up residence in Europe has occupied us for several years now," he writes. ${ }^{29}$ Recalling that he and his wife had enjoyed Baden-Baden, he asks for further details concerning Rosbaud's plan. ${ }^{30} \mathrm{He}$ 's heard nothing as yet from Rufer, but "enthusiastic reports" of Rosbaud's performances have reached him from other directions. "Perhaps," he added, "I shall soon have the opportunity to confirm this for myself." 31 Given the composer's advanced age, his poor health, and the prospect of uprooting his entire family, it is striking that the "only difficulty" Schoenberg could foresee was in the person of Heinrich Strobel. "Dr. Strobel already serves two gods, Hindemith and Stravinsky," he writes, "and I doubt that he will have more enthusiasm left over for me than before the war." But he would be satisfied with a "declaration" from Strobel indicating that he would be "kindly disposed and objective" towards him. ${ }^{32}$

Schoenberg's apprehension was understandable, for Strobel had been a leading advocate of both Hindemith and Stravinsky during the Weimar period. His 1928 monograph on Hindemith was the first book devoted to that composer, while his support of Stravinsky is amply displayed in the pages of Melos. Schoenberg's most vivid memory of Strobel was surely their "violent discussion" of his music that was broadcast over Berlin Radio on 30 March 1931.33 But although the works of Hindemith and Stravinsky occupied a prominent place at the Südwestfunk during the early postwar years (an obvious reason being the easy availability of the music, their publisher, Schott's, having kept

29 "Die Idee in Europa Wohnsitz zu nehmen, hat uns schon seit einigen Jahren beschäftigt." The Schoenbergs had thought of emigrating at least as early as the autumn of 1944, after the composer's retirement from UCLA. At that time they had considered moving to New Zealand, where Gertrud Schoenberg had relatives (Letters, 219-20).

30In the spring of 1930 the Schoenbergs had taken an extended holiday at the fashionable spa town-from whence on 3 May the composer complained to F. C. Adler, musical consultant for Heinrichshofens Verlag, that he had not been informed about Frankfurt Radio's performance of the Begleitmusik zu einer Lichtspielszene, discussed above (LC).

31 "Rufer hat mir von diesem Plan noch nichts geschrieben, aber von anderen Seiten ist mir von Ihren Aufführungen enthusiastisches berichtet worden. Aber vielleicht werde ich jetzt bald Gelegenheit haben, mich davon selbst zu überzeugen." During the previous season Rosbaud had conducted Schoenberg's second Chamber Symphony, op. 38 in Hamburg and Munich.

32"Ich sehe nur eine Schwierigkeit: Dr. Strobel dient schon zwei Göttern, Hindemith und Stravinsky, und ich zweifle, daß er für mich mehr Eifer übrig haben wird als vor dem Kreige. . . . Aber mir würde eine Erklärung Strobels, daß er mir mit wohlwollender Objektivität gegenüberstehen würde, genügen." Schoenberg had written to Wassily Kandinsky on 3 July 1946 that his followers "all rank Hindemith, Stravinsky, and Bartók if not above me at least as on a par with me... But 'thou shalt have one God'...." (Letters, 243).

33Hans Heinz Stuckenschmidt, Arnold Schoenberg: His Life, World and Work, trans. Humphrey Searle (New York: Schirmer Books, 1978), 341. The third participant was the rather conservativeminded critic Eberhard Preussner. "Schönbergs Musik is die letzte Übersteigerung des romantischen Subjektivismus," Strobel had declared on this occasion. "Nur Auserwählte verstehen sie." See NonoSchoenberg, Arnold Schönberg, 283, which also reproduces the text of the composer's reply. 
both composers in its catalogue throughout the Nazi period), there is little reason to suspect that Strobel behaved other than "objectively" towards Schoenberg's music. On 31 January 1951, for example, he offered the composer a commission for a work to be premiered that autumn at the Donaueschingen festival, while on 19 November of that year he revealed to Rudolf Kolisch that Rosbaud and he were interested in presenting the world premiere of Moses und Aron at the 1952 festival. ${ }^{34}$

Eager to learn the details of Rosbaud's plan, Schoenberg followed up his reply to Rosbaud with a letter written on 29 September 1948 to Rufer, who on 17 October promised to contact the conductor. Several months passed without further news from Baden-Baden. "I'd like to know what's happened with Rosbaud," Schoenberg wrote to Rufer on 18 January 1949. "Is he gone over entirely to Hindemith?" Ever distrustful of Strobel, he added, "Paulchen is a good schemer, and Strobel surely gave him a hand." 35 Schoenberg's comments on Hindemith were probably occasioned by the younger composer's visit to the Südwestfunk the previous October. The well publicized occasion marked Hindemith's first postwar conducting engagement in Germany, and was the only concert he conducted in that country during his 1948 trip.

With the aid of OMGUS, Rufer was finally able to reach Rosbaud by telephone from Berlin at the end of January. ${ }^{36}$ On 7 February Rosbaud wrote Schoenberg a long letter. Though clearly uncomfortable with having to query the composer about his private circumstances, and especially about his financial situation, Rosbaud poses four questions to which, he writes, answers are essential if he is to proceed with his plan. Firstly, how many people would be involved in a move? Secondly, is Schoenberg's financial position such that he could help defray his living expenses? Thirdly, does he have any binding commitments, either professional or personal, that would affect the timing of the move? Finally, what would be the conditions under which he could decide to make this move? ${ }^{37}$

Schoenberg lost no time responding in full to Rosbaud's letter. In his reply of 15 February he cautions that he cannot commit himself to a permanent move

34Both letters are published in Heinrich Strobel, "Verehrter Meister, lieber Freund . . " Begegnungen mit Komponisten unserer Zeit, ed. Ingeborg Schatz (Stuttgart: Belser Verlag, 1977), 83. Nothing came of these plans.

35 "Ich möchte auch wissen, was mit Rosbaud passiert ist. Ist er ganz an Hindemith übergegangen? ... Aber Paulchen ist ein guter Intrigant und Strobel hat sicher mitgeholfen.” Three weeks later, on 8 February, Schoenberg wrote to Rufer, "I'm very curious to learn what Rosbaud will suggest, since apparently Hindemith has somehow stolen a march on me. He is really very clever." ("Ich bin sehr neugierig, was Rosbaud mir vorschlagen wird, denn scheinbar ist mir der Hindemith irgendwie zuvorgekommen-er ist ja sehr tüchtig.")

36Letter of 31 January 1949 to Schoenberg. Rufer reported that he had also approached John Evarts, Music and Theater Officer for OMGUS, about the possibility that that organization might fund a series of lectures by Schoenberg in Germany. The composer replied enthusiastically on 8 February (see Nono-Schoenberg, Arnold Schönberg, 416), but nothing came of this plan.

37Rosbaud reported that Peter Stadlen had recently played Schoenberg's Piano Concerto at the Südwestfunk. Stadlen, who had premiered the work at Darmstadt the previous summer, declared that "our performance was the best by far that he had ever given." ("Er erklärte immer wieder, daß unsere Aufführung in unvergleichlicher Weise die beste gewesen wäre, die er je gespielt hätte.") A recording made the day before the performance of 30 January 1949 is no longer extant. 
until after a trial period to determine whether his health can tolerate the climate. Understandably, he is also concerned to know whether the present situation in Germany is such that he and his wife could forget the wrongs of the past. ${ }^{38} \mathrm{He}$ would have to know exactly what would be expected of him, and the demands that would be made on his time. He would also want to receive appropriate remuneration. "I don't expect to return to America loaded with money," he writes, ${ }^{39}$ but he would want to be able to enjoy in Germany the comforts he has become accustomed to in America. At his age these would be difficult to relinquish.

They are a family of five, Schoenberg reports; the children are seventeen, twelve and eight years old. ${ }^{40}$ The entire family would be involved in the move. He has often considered putting the children in a Swiss boarding school, but that is difficult to judge from a distance. As to his financial situation, they own "a valuable piece of land with house and garden," he has a "certain income" from ASCAP, and he should also receive something from his publishers. ${ }^{41}$ (But this money, he points out, really belongs to his heirs.) Apart from private students he has no binding commitments. His daughter graduates from high school at the end of June, and he would prefer to stay until then. But if necessary he and his wife could be in Germany as early as the middle of June, with their daughter to follow later.

Since he would like to be able to enjoy in Germany his present living standard, Schoenberg describes in detail his Los Angeles house. It has three bedrooms, servant's quarters, a two-room combination studio-library, a very large living room, and a lovely dining room and breakfast room. The house has gas central heating and hot water, and three bathrooms. Three bathrooms would hardly be possible in Germany, he admits, but two would be necessary if the whole family were there. Moreover, they have a car ("absolutely essential in Los Angeles"), which they would probably want to bring with them. Seemingly a trifle embarrassed by his thoroughly American life style, Schoenberg points out that they eat simply. "We are not extravagant in this regard; the same goes for drinking." 42 What would complicate the move, he adds, would be the transport of his furnishings, especially his library. He admits that he is a difficult case, but since he would like to give something of himself, he encloses a provisional outline for a twelve-week lecture course. Doubting, however, that

38 Schoenberg had alluded to this in his letter to Rufer of 8 February. The most important condition for a move, he wrote, was a place where he could live, "that is to say, in terms of my health-if the moral conditions, etc. are also comfortable enough." ("Zu Ihrer Frage über meine Bedingungen für eine Übersiedlung nach Deutschland muß ich sagen, daß das wohl erst in Frage käme, wenn ein Platz gefunden wäre, an dem ich leben kann - gesundheitlich, nämlich, wenn die Bedingungen, moralisch u.s.w. auch angenehm genug sind.")

39 "Ich erwarte nicht, daß ich mit Schätzen nach Amerika zurïckkehre ..."

$40 \mathrm{~A}$ photo of the Schoenberg family taken in 1949 can be found in Nono-Schoenberg, Amold Schönberg, 417, which also includes two short excerpts from Schoenberg's 15 February letter to Rosbaud (on pp. 416 and 417).

41 "Wir besitzen ein wertvolles Grundstück mit Haus und Garten, und ich habe auch ein gewisses Einkommen von der ASCAP."

42"Außerdem haben wir, was in Los Angeles eine Lebensnotwendigkeit ist, ein Auto. . . Also Essen ist jedenfalls normal, darin sind wir nicht überschwenglich, auch im Trinken nicht." 
his health would allow him to travel around to give lectures, he suggests instead that "those who want something from me" could visit him at home. "After all," he comments wryly, "one does have to go to Bayreuth." 43

The detailed proposal comprises two pages of largely single-spaced typescript and is divided into three units. It is published here for the first time (see figure). The first and most detailed unit is devoted to aspects of sonata form. The second unit deals with variation technique. After discussing theme and variation form (specifically Beethoven's C-minor and Diabelli Variations, and Brahms's Haydn Variations), Schoenberg moves to an examination of the technique of variation in "other works" (presumably those not employing Theme and Variation form); the unit then concludes with a section on the principle of "developing variation." The third unit is devoted entirely to Schoenberg's own music. It deals with a group of (unspecified) "chambermusic and orchestral works from my most important stylistic periods," analyzed in light of the principles examined in the previous units.

Not surprisingly, Schoenberg's proposal draws on the pedagogical works that were a result of his teaching activities during his American years, most notably his recently completed Fundamentals of Musical Composition. ${ }^{44}$ Striking, however, is the emphasis that Schoenberg places here on his own works, one that is absent in his pedagogical writings. This is surely the result of the reawakened interest in his music on the part of European audiences. "I simply cannot tell you how overjoyed I am about everything I've heard recently from Rufer and you and Zillig," Schoenberg writes in his letter of 15 February. "It is such a pleasure to see the response that my music has awakened." Whatever may come of Rosbaud's plan to bring him back to Germany, "it has in any case brought me great joy." $45 \mathrm{He}$ hopes that his health will permit him to fulfil Rosbaud's intentions. "There are indeed difficulties," he admits in closing, "but I don't believe they're insurmountable." 46

Rufer's opinion, which was to prove prophetic, was that Rosbaud may have taken on more than he could handle. ${ }^{47}$ Acting on his own initiative, Rufer contacted Yehudi Menuhin for advice. On 2 April he reported to Schoenberg that although he (Rufer) had not requested Menuhin's financial support, the violinist had generously offered to contribute the proceeds of one of his German concerts to pay for the composer's travel to Baden-Baden. Rufer

43"Es [wäre] ein viel besseres Arrangement, wenn ich einen ständigen Wohnsitz hätte und die jenigen, die von mir etwas haben wollen, zu diesem Ort kommen. Schließlich und endlich wird auch Bayreuth nicht in jedes Haus zugestellt."

44 This work, completed in 1948, was first published nearly twenty years later. Arnold Schoenberg, Fundamentals of Musical Composition, ed. Gerald Strang and Leonard Stein (London: Faber and Faber, 1967).

45 "Ich kann Ihnen gar nicht sagen, welche Freude mir alles das macht, was ich jetzt von Rufer und von Ihnen und von Zillig erfahren habe. Die Nachrichten sind so angenehm und es ist ein solches Vergnügen, $\mathrm{da} B$ ich doch sehe, welchen Widerhall meine Musik erweckt. . . Was immer nun draus werden mag, so hat es mir ebenfalls eine sehr große Freude bereitet." Winfried Zillig, conductor at Frankfurt's Hessischer Rundfunk, was making arrangements for special performances for the summer of 1949 to honour Schoenberg's seventy-fifth birthday. See also note 54 below.

46 "Es sind wohl Schwierigkeiten, aber ich glaube nicht, daß sie unüberwindlich sind."

47Letter to Schoenberg, 16 March 1949. 


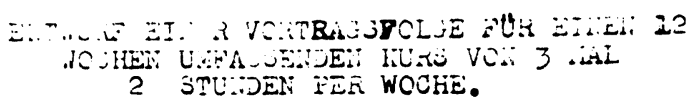

Die hier anjegebenen Gegenstände werden in pielen

Fllile mehr als elnen Klassentag beanspmachen.

Sie werden durch Belsplele aus der Literatur 1llustriert

sein, wozu warschelnlich ein Projektor erforderlich sein

wird.

Die a igegebene Reihenfolge 18t noch nicht bindend.

I). Konstuktion des ersten Tells elner Sonate, elnes zuartettsatz, Symphomle etc.

1). Was 1st an tematischen Materlal erforderlich.

2). Kharakteristik der Themen in hinsicht auf ihre Stellung und Bedeutung.

3). Der mot1vische Zusammenhang der Themen.

4). Verhalten der Harmonie.

5). Mittel der Erzeugung der nbtigen Kontraste.und elnes fliesDix

6). D1e Technik der toerle1tung. senden Verlauf der darsteliung der Gedanken.

7). Erzeugung von verschiedenenArten von Schillssen.

8). Die Technik der Iiquidierung.

II).

D1e Durchrlhrung, der kontrast1erende M1tteltell.

1). Grundsltzliche Verschiedenhe1t der Konstruktion der zusammensetzenden Elemente.

2). Der modulatorische Ablauf der Harmonie, sein wer und sein Ziel.

3). Durchfuhming elnes efnzigen Themas.

4). Durcheulheung mehrereh Themen.

a) In loser Aufeinanderfolge.

b) In kontrapunktischer oder polyphoner Komaination.

5). Arten der Verbindung oder Gegendberstellung der elnzelnen Telle.

a) Durch tberghtnge verbunden.

b) Als Gegensltze nebeneinander gestellt.

c) Durch Liquidierungen von elnander getrennt.

6). Die Rulckfuhmung und Vorbereitung ettextia der Repriese.

a) Elnfaches hindberfliessen wie in Nozart etc

b) Erzeugung elner dramatischen Spannung wie in Beethoven.

III). D1e Repriese, ale notwendige und unnotwendigen tnderunen. 1) Jie tonale Stelluns derSektensatzgoupe

Figure. Arnold Schoenberg, "Draft for a series of lectures for a 12-week course meeting for two hours three times a week," 15 February 1949. Photo courtesy of the Hans Rosbaud Papers, Washington State University Libraries, Pullman, Wash.; reproduced with the kind permission of the Schoenberg family. 
"

2) D1e"sch1cksallharten" Verknormungen im Hauptthema und €ventuell auch im Seltenthema.

3) Die Verlanderungen in der Satzwe1se oder Instrumentation trotz unvirkndertem Charaktar und Ausdruck.

4) Kleine Varianten und Variationen in Hebens Hchlichem.

IV)

Die Coda.

1) Kurzere schlueslize bestehen aus:

a) Karzerekadenzartigez Einhe1ten imehreren

b) aus/rasih rickehrendenModulationen, imehreren die Mot1veragmente verarbeiten.

c) Liqudationartige Reduktion solcher E1nheiten funrt zurdok zur Tonika.

2) Ingedehntere und selbstindigere Kodasltze bestehen aus meheeen tolchentruppen diedann auch harmonlsch kontrastieren. Das elgentliche Ende 1ot dann Ehnlich ausgeflhrt wie die ubter 1) beschriebenen klrzeren Kodas.

Elne gew18se Ihnlichrie1t m1t einer Durchellhrang 18t oft nathwe1sbar.

$$
1-0-0-0-0-0-0-0-1
$$

I0. DIE TDNHNIK DER VARIATION

1. Illustriert durch Beethovens $C$ Moll und Diabell1 Variationen und Brahms Variationen Uber ein Thema von Haydn.

(DieseriAnelysen werden Henlgstens 3 b18 4 Elassen erfordern.)

21)D1e Anwendung der Varlationentechnik in aderen ierken. IJj)Die Technik der entwickelnden Varietion.

$$
10-0-0-0-0-0-0-0-01
$$

ANALYSEN EINER REIHE MEINER EIGENEN WERKE AUF DER GRUIDLLGE DER VORHERT DARGESTEILTEN THEORETISCHEI BASIS.

Es kommen in betracht Kammermusik und Orchesterwerke ineiner wichtigsten ST1Iperioden

$$
27-5-3-2-3-3-3-2-7-(
$$


reported that Edward Lockspeiser at the BBC and Rolf Liebermann at Radio Zurich were also ready to help. ${ }^{48}$

On 8 April Schoenberg complained to Rufer that he had not heard from Rosbaud since he had sent him the course proposal in mid-February. Ever mistrustful, the composer's suspicion now alighted on the American composer who was later to be the object of his public attack. "You know Copland, I think," he wrote. "It's possible that the delays can be attributed to this man." 49

This comment of Schoenberg's preceded by several months a protracted affair precipitated by his "birthday blast" in the pages of the New York Herald Tribune. ${ }^{50}$ On 11 September 1949 Virgil Thomson included in his "Music in Review" column a short statement by Schoenberg, scheduled to be broadcast that same day as part of a series of programmes honouring the composer's seventy-fifth birthday, in which Schoenberg accused Arturo Toscanini, Sergey Koussevitzky, Bruno Walter-and Aaron Copland-of trying to suppress his music. Clearly, Schoenberg's reason for attacking the three leading conductors of the day was that they did not perform his music, while his attack on Copland, whose name he coupled with that of Joseph Stalin, was apparently prompted by that composer's position as the most prominent of the American (i.e., "nationalistic") composers. Copland's indignant response was published in Thomson's column of 25 September. Schoenberg replied on 23 December in a letter to Thomson, explaining that he had compared Copland to Stalin because both men forced young composers to write in a particular style. ${ }^{51}$ Nor was this the first time that Schoenberg had accused American composers of Staliniststyle tactics. On 12 April of the same year he had written to Rudolf Kolisch, "The tendency [in America] is to suppress European influences and encourage nationalistic methods of composition constructed on the pattern adopted in Russia and other such places." 52

On 1 July 1949 Rosbaud penned the long-awaited reply to Schoenberg's letter of mid-February. He had little in the way of concrete progress to report. After meetings with members of the French military in Baden-Baden, he had consulted directly with the Ministry in Paris. There is widespread enthusiasm for the plan, he assures the composer, but in such an important matter, "I cannot be satisfied with promises made in the flush of enthusiasm." 53 Success will

48Rufer reported the BBC's in-principle agreement in his letter of 2 April; on 12 April he informed Schoenberg of Radio Zurich's interest.

49 "Sie wissen Copland, meine ich. Möglich daß auch auf dieser Herrn die Verzögerungen zurückzuführen sind."

50The quotation is from Virgil Thomson's "Music in Review" column of 25 September 1949.

51 Full documentation for this affair can be found in Egbert M. Ennulat, Arnold Schoenberg Correspondence: A Collection of Translated and Annotated Letters Exchanged with Guido Adler, Pablo Casals, Emanuel Feuermann and Olin Downes (Metuchen, N.J. and London: The Scarecrow Press, 1991), 259-77. This includes Thomson's "Music in Review" columns of 11 and 25 September 1949; Schoenberg's reply of 23 December to Thomson; Copland's letter of 13 February 1950 to Schoenberg (in which he denied Schoenberg's charge and declared his appreciation of the older composer's accomplishments); and Schoenberg's partly conciliatory reply to Copland, dated 21 February.

52Letters, 270.

53 "Sie sehen . . . daß ich mich nicht mit Versprechungen begnügen kann, die in der ersten Begeisterung getan werden." 
hinge ultimately on commitments from the local authorities, namely, the municipal leaders (responsible for arranging accommodations for the composer and his family), and the Südwestfunk (as holders of the artistic initiative). Since the radio station is undergoing a management crisis, he has not yet been able to obtain a definitive commitment from that quarter. As for the municipal authorities, they will regain control of the city's accommodations only in the autumn. By then he should have news to report. He regrets that Schoenberg had not been able to travel to Darmstadt that summer, which would have given them an opportunity to discuss their plans in person. ${ }^{5+}$

Nearly a year passed before Rosbaud's next letter. On 26 April 1950, having learned that the violinist Tibor Varga had performed his Violin Concerto with Rosbaud at Cologne Radio, Schoenberg requested from the conductor a recording of the performance. An American record company, he added, was interested in the possibility of issuing Rosbaud's performances of both the violin and piano concertos. ${ }^{55}$ Surely realizing by this time that Rosbaud's plan must have floundered, Schoenberg avoids mentioning it directly. "I have heard nothing from you now for a long time," he writes. "Why? I thought that perhaps you've given up on me. That would be a pity." 56

Understandably pained by Schoenberg's comment, Rosbaud hastened in his reply of 6 June to assure the composer of his devotion. He confessed that his failure to write was due to "a certain feeling of shame at not being successful in realizing my plan." ${ }^{57}$ Although the administration of the city is now under the control of the civil authorities, he reports, prospects for his plan have unfortunately not improved.

The last direct contact between Rosbaud and Schoenberg took place three months later, when Rosbaud wrote to thank the composer for sending him a copy of his recently published Style and Idea.$^{58}$ Surprisingly, the significance of the date escaped his attention. It was 13 September 1950, Schoenberg's seventy-sixth (and, as it turned out, final) birthday. Rosbaud had already read parts of Schoenberg's book, he reported, including the essay on Brahms. This experience must have awakened poignant memories, for not only was

\footnotetext{
54Schoenberg had been invited to teach at the Internationale Ferienkurse für Neue Musik in Darmstadt and to attend concerts in honour of his approaching birthday, but ill health had prevented the trip. "I suffer from asthma, I suffer from giddiness, and I also have stomach troubles ...," Schoenberg informed Rufer in May, "I don't think I can risk it" (Letters, 271; see also ibid., 269).

55 Nothing came of these plans, partly for reasons of copyright. Rosbaud's performance of the Violin Concerto with Tibor Varga was part of a broadcast concert of 3 April 1950 at Cologne Radio. On the previous day the radio station had sent the composer a telegram, informing him of the concert. A copy of the Cologne recording preserved at ASC was sent by Varga to Schoenberg the following year. (For the composer's glowing letter of praise, see Letters, 288-89.) Interestingly, Stravinsky first made the acquaintance of the Violin Concerto when he heard the Cologne recording during his visit to the radio station in October 1951; see Robert Craft, Present Perspectives (New York: Alfred A. Knopf), 252.

56 "Ich habe jetzt lange nichts von Ihnen gehört - warum? Ich habe schon gedacht, daß Sie mich aufgegeben haben. Das wäre schade."

57 "Der eigentliche Grund für mein langes Stillschweigen war das Gefühl einer gewissen Beschämung, daß es mir nicht gelungen ist, meinen Plan zu realisieren."

58From 1952 until his death a decade later, however, Rosbaud carried on an extensive correspondence with the composer's widow, correspondence which contains much valuable information concerning his Schoenberg performances.
} 
Schoenberg's essay originally written as a result of Rosbaud's invitation, but the occasion of its delivery, shortly after the Nazi takeover, marked their final meeting.

* * * *

During the 1950s Rosbaud achieved an international reputation, accepting conducting engagements throughout Europe, in the United States, and in such far-flung places as Turkey, Argentina and South Africa. ${ }^{59}$ His keen intelligence and astonishing musical gifts were deployed in performances of a wide repertoire reaching from Bach to Boulez. He was acclaimed not only as a pre-eminent conductor of twentieth-century music, but as one of the great conductors of the day. Yet it was with the music of his own time that Rosbaud's name was, and remains, most closely associated. He became a familiar figure at modernmusic festivals throughout Europe, ${ }^{60}$ especially at Donaueschingen, which was resurrected in 1950 under the auspices of the Südwestfunk. "Without him," Strobel recalled after the conductor's death, "Donaueschingen would have been impossible."61

On 12 March 1954 Rosbaud conducted in Hamburg the first performance of a work with which his name remains inextricably linked: Schoenberg's unfinished opera, Moses und Aron. As is well known, Rosbaud was called in to replace Hamburg Radio's Hans Schmidt-Isserstedt shortly before the concert premiere of the work. Although his prior knowledge of the opera was confined to the "Dance 'round the Golden Calf," which he had conducted to acclaim during the Berlin Festival the previous September, Rosbaud mastered within days the fiendishly difficult score, a feat that cemented forever his reputation as a Schoenberg expert. The performance was a sensational success, and the composer's widow, who had travelled to Germany for the historic occasion, presented the conductor with Schoenberg's baton. Three years later, on 6 June 1957, Rosbaud led the successful stage premiere of the work at the Zurich Opera House, thus confirming the dramatic viability of Schoenberg's masterpiece. That same year the Hamburg performance was released on the Columbia label as the first recording of the work. ${ }^{62}$

59On 20 May 1950 Rosbaud had penned a note to Schoenberg from Ankara to which a number of Turkish musicians added their greetings. These included the composers Necil Kâzim Akses and Ahmet Adnan Saygun (members of the "Turkish Five"), as well as the violinist Licco Amar, who was well known during the 1920s for his performances as a member of the Amar-Hindemith Quartet. Until the Nazi takeover, Amar was concertmaster at Frankfurt Radio.

60For example, Rosbaud conducted the European premiere of Kol nidre, op. 39 at Cologne Radio in a "Musik der Zeit" concert on 13 December 1954; on 12 January 1958, in a Hamburg Radio "Das neue Werk" concert, he presented the first performances of two Schoenberg fragments, Die Jakobsleiter and Israel Exists Again. All three performances were recorded.

61 Heinrich Strobel, “In memoriam Hans Rosbaud," Das Orchester 18 (1963): 19.

62The conductor himself was not entirely satisfied with either the Hamburg or the Zurich performances. To a tentative offer to conduct what would have been the North American premiere of the work at Tanglewood in the summer of 1963 (letter of 7 July 1961 from Walter Surovy), Rosbaud replied one week later (in English), "Ever since I conducted those two performances, I am looking for an opportunity to conduct this Schönberg a third time, under better and more favourable circumstances" (WSU). 
Less spectacular, though more important for Schoenberg's gradual public acceptance, were the dozens of performances of his works that Rosbaud conducted in this final decade of his life. ${ }^{63}$ On 20 May 1952, for example, he presented the French premiere of Erwartung at a month-long international festival in Paris sponsored by the Congress for Cultural Freedom. ${ }^{64}$ In its review of 22 May, Le Figaro pronounced the concert performance of the work "magical," while a young Karlheinz Stockhausen declared enthusiastically that nowhere in the world could a better conductor have been found. ${ }^{65}$ Five years later, in a Domaine Musical concert of 11 October 1957, Rosbaud presented the first performance in Paris in nearly thirty years of Schoenberg's Five Pieces for Orchestra, op. 16. ${ }^{66}$ Rosbaud was especially fond of this work. He programmed it the following season during his first North American engagement, a series of concerts with the Chicago Symphony Orchestra, as well as in December 1960 with the New York Philharmonic. ${ }^{67}$

Erwartung (with Helga Pilarczyk) was a featured work during Rosbaud's first appearance at the Holland Festival in the summer of 1958. At the conductor's suggestion, Von heute auf morgen, not previously performed in that country, was paired with the earlier work. The operatic double bill was acclaimed as the highpoint of the festival, launching, as one critic later recalled, Holland's "Schoenberg era." 68 During the same festival, the conductor made his debut with the Royal Concertgebouw Orchestra in the Dutch premiere of the Variations, op. 31,69 a work that had retained special associations for Rosbaud ever since the 1931 Frankfurt Radio performance in which the composer had participated. ${ }^{70}$ Quite simply, it was Rosbaud's performances of this pathbreaking work that led to its acceptance as a modern classic. Elliott

63For a list of Rosbaud's surviving recordings of Schoenberg's music, see Evans, Hans Rosbaud, 171-75. The list involves recordings (in most cases multiple recordings) of over twenty works.

64In the second half of the concert Rosbaud conducted Stravinsky's Oedipus Rex. The composer later commented that such a double bill would have been "unthinkable" a few years earlier, adding: "I hope Schoenberg would have been pleased. I know I was." Igor Stravinsky and Robert Craft, Dialogues and a Diary (Berkeley: University of California Press, 1982), 106-7.

65Letter of 6 June 1952 to Heinrich Strobel (Südwestfunk archives, Baden-Baden).

66Pierre Boulez, "Recollections of Hans Rosbaud," Foreword to Evans, Hans Rosbaud, x. At the same concert Rosbaud presented the French premieres of Berg's Three Pieces for Orchestra, op. 6 and Webern's Six Pieces for Orchestra, op. 6, while Stravinsky conducted the European premiere of Agon. For his recording of the Berg, Webern and Stravinsky works, released in 1958 on the Vega label, Rosbaud was awarded the Grand Prix du Disque.

67 A live recording of op. 16 with the New York Philharmonic, recorded on 2 December 1960, is preserved at LC (Recorded Sound Division).

68 Piet Schilham, "The Hague Philharmonic: An Advocate of Schoenberg," Journal of the Arnold Schoenberg Institute 6 (1982): 241. Both works were recorded live on 12 July 1958.

69 A recording of the 26 June 1958 performance of the Variations was issued on the Rococo label in 1980 .

70At the 1953 Donaueschingen Festival Rosbaud had been able to relive partially that memorable occasion. His performance of the Variations with the Südwestfunk orchestra was introduced by a tape recording containing portions of Schoenberg's radio lecture. See Joan Evans, "Im Zeichen Hans Rosbaud (1948-1962)," in Orchester Kultur. Variationen über ein halbes Jahrhundert, ed. Jürg Stenzl (Stuttgart and Weimar: Metzler, 1996), 22-23. A Cologne Radio recording of the Variations from 12 April 1953 preserves Rosbaud's first postwar performance of the work, while a live recording of the Donaueschingen performance is preserved at the Internationales Musikinstitut Darmstadt. 
Carter spoke for many of his contemporaries when he recalled that Rosbaud's Baden-Baden performance of June 1955 "left us all completely convinced of its greatness."71 Pierre Boulez, who heard Rosbaud perform the Variations with the Südwestfunk orchestra at the Vienna Festival in June 1961, recalled that the performance "was simply a perfect stream of music," a view shared by Herbert von Karajan, who was also present. ${ }^{72}$ The previous month Rosbaud had recorded the work for the Südwestfunk, a performance which was released on the Wergo label after his death.

Rosbaud made relatively few commercial recordings during his lifetime, and until the advent of digital technology his Schoenberg discography consisted of the two releases, Moses und Aron (1957) and the Variations, op. 31 (1967), mentioned above ${ }^{73}$ Happily, the conductor's centennial in 1995 prompted a number of new releases and re-releases. Most notably, Wergo (in collaboration with the Südwestfunk) issued three works from Rosbaud's valuable legacy of Schoenberg recordings made at the radio station in the 1950s: Ode to Napoleon, op. 41 (1953); Pierrot lunaire, op. 21 (1957); and Five Pieces for Orchestra, op. 16 (1958). A live performance from the 1958 Holland Festival of Von heute auf morgen on the Stradivarius label completes Rosbaud's modest discography of Schoenberg performances to date. ${ }^{74}$ The conductor's many admirers can only hope that more of his standard-setting recordings will find their way into the catalogues, for only then will it be possible to assess the full significance of Rosbaud's contribution to the music of Arnold Schoenberg, the composer whom he revered as "the greatest musical thinker of our time." 75

\section{Abstract}

This study documents the efforts of Hans Rosbaud (1895-1962) on behalf of the music of Arnold Schoenberg. It is largely based on the twenty-year correspondence between conductor and composer, most of which remains unpublished. Rosbaud's efforts already bore fruit during his tenure at Frankfurt Radio in the early 1930s. After the forced hiatus of the Nazi years (during which he worked in Germany and occupied France), Rosbaud achieved an international reputation as the Schoenberg conductor par excellence. His activities on Schoenberg's behalf involved a plan, previously unremarked in the Schoenberg literature, to bring the aging composer back to Germany.

71Letter to the author, 3 October 1988. A performance of the Variations at Darmstadt the previous month had been hailed as the highpoint of the concert.

72 Pierre Boulez, "Recollections of Hans Rosbaud," xii.

73 But see also note 69 above.

74WER 6403-2, released in 1993, is one of a series of compact discs issued as the "Hans Rosbaud Edition"; Von heute aufmorgen was released as STR 10054 in 1992. For a full discography of Rosbaud releases and re-releases up to 1992, see Evans, Hans Rosbaud, 91-106.

75 “. . . die gröflte musikalisch-geistige Persönlichkeit unserer Zeit . ..” Statement of 5 April 1954 to the Entschädigungsamt, Berlin (written at the request of Gertrud Schoenberg) (WSU). 


\section{Résumé}

Cette étude documente les efforts de Hans Rosbaud (1895-1962) pour promouvoir la musique d'Arnold Schoenberg. L'essai est en grande partie basé sur vingt années de correspondance entre le chef d'orchestre et le compositeur, échange demeuré inédit. Les tentatives de Rosbaud portaient déjà fruit pendant qu'il était en fonction à la radio de Francfort au début des années 1930. À la suite de l'interruption forcée due aux années nazies (au cours desquelles il a travaillé en Allemagne et dans la France occupée), Rosbaud a acquis une réputation internationale en tant que chef d'orchestre par excellence dédié aux œuvres de Schoenberg. Ses activités en faveur de Schoenberg dissimulaient le projet, que la littérature sur celui-ci n'avait pas encore relevé, de ramener le compositeur vieillissant en Allemagne. 